\title{
Kropps- eller hodetransplantasjon?
}

\author{
Det er ikke hodet, men kroppen som transplanteres.
}

Nylig har en påstått planlagt hodetransplantasjon vært omtalt i mediene (1). Ifølge nyhetsartiklene skal man forsøke å gi en pasient en ny kropp. På sosiale medier ser jeg at flere kolleger omtaler prosedyren med stor iver. Bevissthetssenteret tatt i betraktning vil min organisme foretrekke en kroppstransplantasjon kontra en hodetransplantasjon når som helst.

Kan vi ikke bli enige om at det skal hete kroppstransplantasjon istedenfor? Da kan mine kollegers kropp få beholde sitt bevissthetssenter og de slipper at hjertet styrer tankene. Så blir heller ikke Descartes’ord «jeg tenker, altså er jeg» husket forgjeves.

\section{$\emptyset y s t e i n$ B. Tandberg}

oystein.tandberg@gmail.com

Øystein B. Tandberg (f. 1981) er lege i spesialisering ved Ortopedisk avdeling, Haukeland universitetssykehus.

\section{Litteratur}

1. Griffin A. Head transplant: Russian man to become first to undergo pioneering and controversial surgery. The Independent 8.4.2015.

www.independent.co.uk/news/science/headtransplant-russian-man-to-become-first-toundergo-pioneering-and-controversial-surgery10162639.html (26.5.2015).

Mottatt 12.4. 2015 og godkjent 1.6. 2015. Redaktør: Erlend Hem.

\section{E. Hem svarer:}

Så er vi i gang igjen med medieomtaler av stormannsgale kirurger med ambisjoner om å ommøblere hoder og kropper (1). Det er ikke første gang. For noen år siden brakte avisene nyheten om at den amerikanske nevrokirurgen Robert White (1926-2010) hadde transplantert et apehode fra en kropp til en annen. «Jeg vet ikke om jeg vil kalle det hodetransplantasjon eller kroppstransplantasjon», uttalte nevrobiologen Steven Rose den gangen. «Uansett er dette et medisinsk og teknologisk blindspor», sa han (2).

Øystein B. Tandberg skal ha ros for å ta tak i det (eneste) interessante aspektet ved tøvet - nemlig hva vi kaller det. Skal det Ika-

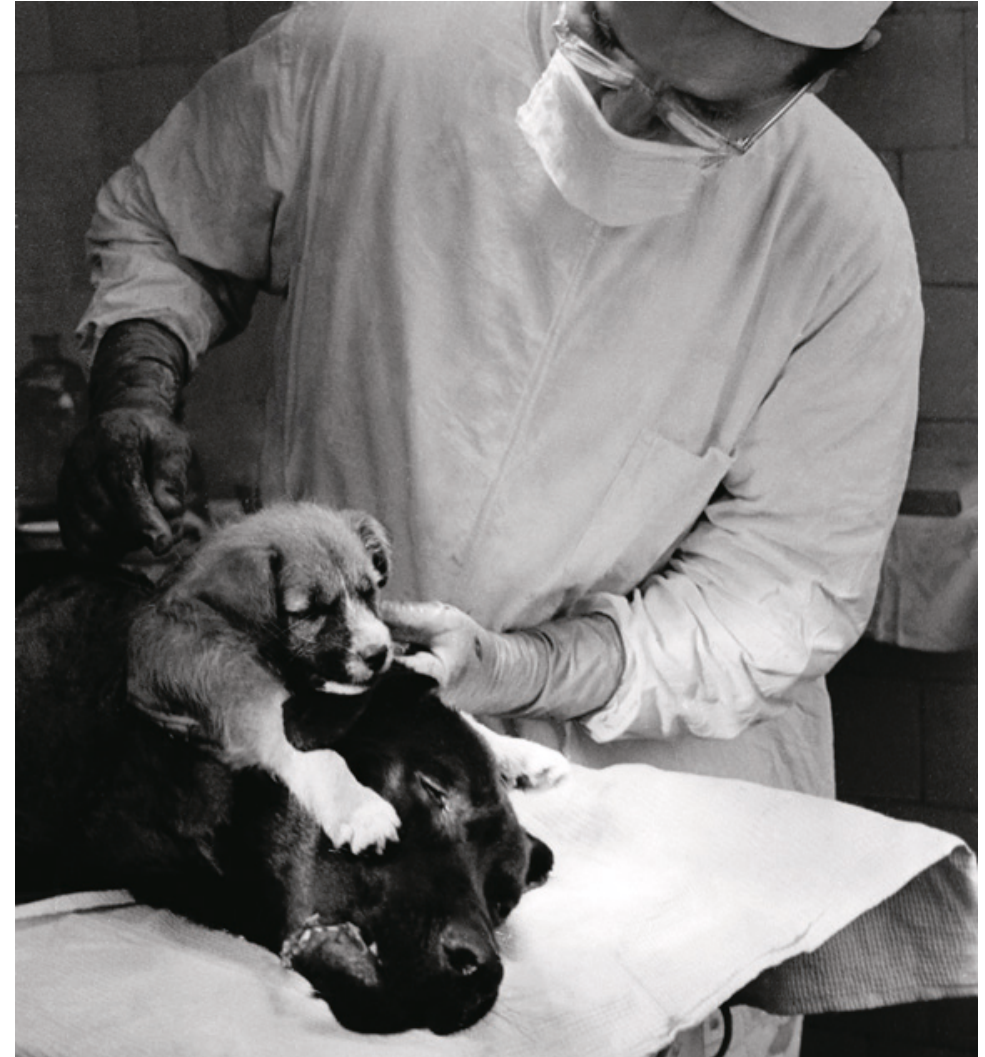

Den sovjetiske kirurgen Vladimir Demikhov (1916-98) var en pioner innen transplantasjonskirurgi. Han ble berømt for eksperimenter med å transplantere hoder på hunder, første gang i 1954. Resultatene var dårlige. Dette bildet er fra 1967. Foto Science Photo Library

ros-liknende transplantasjonsprosjektet kalles hode- eller kroppstransplantasjon? På engelsk finner man igjen samme problem, både «head transplant» og «body transplant» er i bruk. Jeg er enig med Tandberg i at det tross alt er kroppen som transplanteres, ikke hodet - altså kroppstransplantasjon.

Saken er komplisert. Riktignok er bevisstheten utvilsomt og sannsynligvis entydig knyttet til hjernen. Det er likevel ikke slik at det finnes ett bevissthetssenter i hjernen. Faktisk er ingen riktig sikre på hvor bevisstheten egentlig sitter - eller for den saks skyld nøyaktig hva bevissthet egentlig er. Nettverksmoduler knyttet til hjernestammen er med stor sannsynlighet involverte, men også andre hjerneavsnitt er kandidater. Uttrykket «bevissthetssenteret» bør derfor utgå eller erstattes. Det er holdepunkter for at både selvet og bevisstheten i større eller mindre grad er knyttet til kroppsopplevelsen, ikke bare hjernen (engelsk: embodied). Nevrobiologen Antonio Damasio anbefales for en nærmere redegjørelse for dette.

\section{Erlend Hem}

erlend.hem@medisin.uio.no

Erlend Hem (f. 1970) er dr.med. og redaktør for Tidsskriftets språkspalte.

\section{Litteratur}

1. Avner T. Kirurg: Jeg kan transplantere en ny kropp om to år. Aftenposten 27.2. 2015. www.aftenposten.no/fakta/innsikt/Kirurg-Jegkan-transplantere-en-ny-kropp-om-to-ar7917409.html (1.6.2015)

2. Johnsen B. Ape fikk ny kropp. VG 7.4.2001. www.vg.no/nyheter/utenriks/ape-fikk-ny-kropp/a/ 5589328 (1.6.2015). 